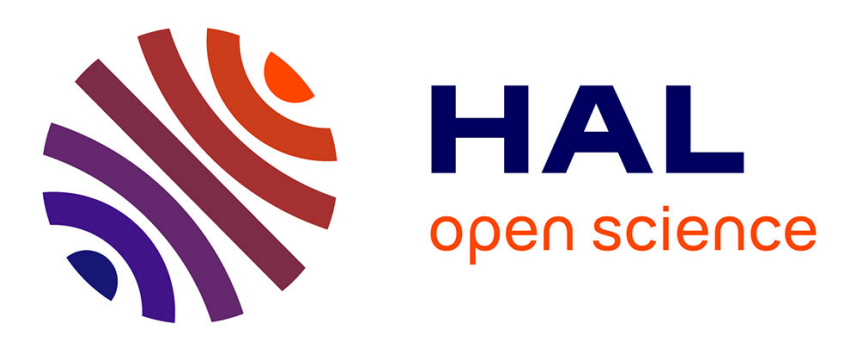

\title{
Floral oil collection by male Tetrapedia bees (Hymenoptera: Apidae: Tetrapediini)
}

Simone Cappellari, Gabriel Melo, Antonio Aguiar, John Neff

\section{To cite this version:}

Simone Cappellari, Gabriel Melo, Antonio Aguiar, John Neff. Floral oil collection by male Tetrapedia bees (Hymenoptera: Apidae: Tetrapediini). Apidologie, 2011, 43 (1), pp.39-50. 10.1007/s13592-0110072-2 . hal-01003609

\section{HAL Id: hal-01003609 \\ https://hal.science/hal-01003609}

Submitted on 1 Jan 2011

HAL is a multi-disciplinary open access archive for the deposit and dissemination of scientific research documents, whether they are published or not. The documents may come from teaching and research institutions in France or abroad, or from public or private research centers.
L'archive ouverte pluridisciplinaire HAL, est destinée au dépôt et à la diffusion de documents scientifiques de niveau recherche, publiés ou non, émanant des établissements d'enseignement et de recherche français ou étrangers, des laboratoires publics ou privés. 


\title{
Floral oil collection by male Tetrapedia bees (Hymenoptera: Apidae: Tetrapediini)
}

\author{
Simone C. Cappellari ${ }^{1}$, Gabriel A. R. Melo $^{2}$, Antonio J. C. Aguiar ${ }^{3}$, John L. NefF ${ }^{4}$ \\ ${ }^{1}$ Section of Integrative Biology, The University of Texas at Austin, One University Station A6700, Austin, TX \\ 78712, USA \\ ${ }^{2}$ Lab. Biol. Comparada Hymenoptera, Departamento de Zoologia, Universidade Federal do Paraná, Caixa Postal \\ 19020, BR-81531-980, Curitiba, Paraná, Brazil \\ ${ }^{3}$ Departamento de Zoologia, Universidade de Brasília, Campus Universitário Darcy Ribeiro, BR-70910-900, \\ Brasília, Distrito Federal, Brazil \\ ${ }^{4}$ Central Texas Melittological Institute, 7307 Running Rope, Austin, TX 78731, USA
}

Received 14 February 2011 - Revised 24 April 2011 - Accepted 23 June 2011

\begin{abstract}
Several groups of solitary bees, known as oil-collecting bees, gather lipids from flowers that offer them as their main reward to pollinators. In the Neotropical region, oil-collecting bees belong to the tribes Centridini, Tapinotaspidini, and Tetrapediini (Apidae: Apinae). The floral oils collected by females of these groups are used as larval food or in nest construction. The interaction of these bees with oil flowers is characterized by the presence of specialized structures for oil collection on the legs that morphologically match the location and type of the oil-producing glands on flowers they visit. In addition, these bees have specialized arrays of setae (including the scopae) for oil transport. In a few genera, both sexes display such specialized structures, although floral oil collection has hitherto been regarded as an exclusively female task. Here, we report floral oil collection by males of Tetrapedia, a Neotropical genus of oil-collecting bees. We describe behavioral aspects of oil foraging by males, present data on morphological structures associated with the collection of this resource, and discuss potential hypotheses to explain the significance of floral oils in the mating system of Tetrapedia.
\end{abstract}

Cerrado / mating / Neotropical / oil-collecting bees / oil flowers / solitary bees

\section{INTRODUCTION}

Male and female bees often differ in their foraging apparatuses, floral preferences, and foraging behavior. These differences are typically associated with the purposes for which each sex forages for resources (Eickwort and Ginsberg 1980). Male bees normally do not contribute to

Corresponding author: S.C. Cappellari, scappellari@gmail.com Manuscript editor: David Tarpy either parental care or nest construction, tasks which are performed by females. Males usually visit flowers to acquire resources for their own feeding, for mating, or more rarely, to obtain resources used in mating (Eickwort and Ginsberg 1980). Since male bees usually forage only for nectar, for which only the mouthparts are used, they typically lack the numerous specialized structures possessed by females to collect and transport floral resources such as pollen, resin, or fatty oils (Michener 2007). Specialized modifications of the body appendages are common in male bees, but their presence usually is associ- 
ated with mating behaviors such as signaling or grasping potential mates (Anzenberger 1977; Dressler 1982; Norden and Batra 1985; Wirtz et al. 1988; Wittmann and Blochtein 1995; Michener 2007).

A notable exception to this pattern is found among certain oil-collecting bees. The oil bees are a polyphyletic assemblage of roughly 400 species occurring on all continents except Antarctica (Michener 2007). Female oil bees collect fatty oils from specialized glands (elaiophores) found on the flowers of more than 1,600 plant species from 11 angiosperm families (Renner and Schaefer 2010). These elaiophores vary widely in their form, size, and location (Vogel 1974). Accordingly, different oilcollecting bees have different types of structures to harvest and transport the oils of particular elaiophores types (Vogel 1974; Neff and Simpson 1981; Roig-Alsina 1997). Normally, these structures are found only on the females but in two clades of Neotropical oil-collecting bees, Tetrapediini and Tapinotaspidini (both Apidae: Apinae), the fore legs of the males have structures virtually identical to those that their females are known to use to harvest floral oils (Neff and Simpson 1981; Roig-Alsina 1997). Since the discovery of the oil flower pollination syndrome, scattered field observations have suggested that some males of these two tribes may collect floral oils (Friese 1925; Vogel 1974; Cocucci 1991; Vogel and Machado 1991; Singer and Cocucci 1999; Rasmussen and Olesen 2000; Aguiar and Melo 2009). However, the fragmentary nature of the data has left many unanswered questions about the function of floral oil collection by male bees. Here, we provide direct evidence for active floral oil collection by males of four species of Tetrapedia that repeatedly visited oil flowers of Malpighiaceae in the Brazilian Cerrado.

Tetrapedia (Apidae: Apinae: Tetrapediini) is a Neotropical genus of approximately 28 species of solitary, cavity-nesting bees (Silveira et al. 2002; Moure 2007). Unlike most other oilcollecting bees, both males and females of this genus display a variety of morphological and behavioral features for effective collection of floral oils (Neff and Simpson 1981; Alves-dosSantos et al. 2006, 2007). The oil-collecting structures of Tetrapedia appear to be adapted for harvesting oils from flowers with epithelial elaiophores as found in the Malpighiaceae, and females have commonly been associated with flowers of that plant family (Neff and Simpson 1981). Although females of several Tetrapedia species are known to collect and use floral oils for larval provisioning and nest construction, the presence of similar structures in the males was problematic, since males of this genus, like most male bees, leave their natal nest soon after emerging and spend their lives searching for mates. Detailed observations at nests have established that the males do not provide any form of parental care nor participate in nest construction (Michener and Lange 1958; Roubik 1992; Alves-dos-Santos et al. 2002; Camillo 2005); thus, it was not clear why they have structures that might be used for collecting floral oils. Use of oil as an adult food source, or to play some role in mating behavior have been suggested as possible functions (Neff and Simpson 1981), but no data to either confirm or reject these hypotheses have been previously available. Our data consist of detailed behavioral observations and a morphological study of the male oilcollecting apparatus, including the description of an oil-storage structure found uniquely on males of Tetrapedia. We discuss the possible significance of oil collecting for the mating biology of this group based on our findings and the literature.

\section{MATERIAL AND METHODS}

\subsection{Field sites}

Field observations were independently carried out by the first three authors at various sites within the Brazilian Cerrado. Oil collection by male Tetrapedia was observed by G. A. R. Melo in Tibagi, Paraná (243' S, 50¹6' W; $990 \mathrm{~m}$ ASL) on November 30, 2003; by A. J. C. Aguiar at the Reserva Particular do Patrimônio Natural "Cachoeira do Campo," Serra do Salitre, Minas Gerais (19¹6' S, 46 $56^{\prime}$ W, 1,099 m 
ASL) at the beginning of the wet season during October 2005; and by S. C. Cappellari at the Reserva Ecológica do IBGE (RECOR; 1556' S, 47 $52^{\prime} \mathrm{W}$; $1,087 \mathrm{~m}$ ASL) in Brasília, Distrito Federal, during the wet (October to April) and dry (May to September) seasons 2007-2010.

\subsection{Floral records}

Males of four species of Tetrapedia were recorded collecting oils on flowers of seven Malpighiaceae species. Specimens were collected after observations and killed with ethyl acetate for later study. Pinned specimens were preliminary identified by A. J. C. Aguiar and S. C. Cappellari. Species identity of all collected specimens was later confirmed by G. A. R. Melo using the literature and by comparisons with type material from the Department of Zoology (Coleção Entomológica Padre J. S. Moure) of the Universidade Federal do Paraná (DZUP), Brazil and the Museum für Naturkunde (ZMB), Germany. Bee vouchers were deposited in the entomological collections of the Universidade de Brasília (UnB) and DZUP.

Vouchers for all plants observed at the Brasília site were deposited in the IBGE herbarium and from Tibagi in the UFPR herbarium (UPCB). Vouchers for all plants observed were determined by Dr. M. C. Mamede from the Instituto de Botânica de São Paulo, Brazil.

\subsection{Morphology of oil-collecting structures in Tetrapedia males}

Morphological examination of male oil-collecting and storage structures was done on specimens of Tetrapedia diversipes Klug and Tetrapedia aff. peckoltii Friese using a stereoscope $(\times 100)$. Color photographs of male oil-collecting structures were taken using a JVC KY-F70 digital camera mounted on a Leica Z6 APO dissecting scope. Composite images were assembled from 20 sequential photographs with Syncroscopy AutoMontage (v 5.0) software. Scanning electron micrographs (SEM) were recorded using a Zeiss Supra 40 VP. Unless otherwise specified, mounted bees were washed in ethyl acetate to remove any oily residues to better determine the morphology of their oil-collecting structures. Specimens were mounted on SEM stubs and coated with a 15-nm layer of platinum-palladium.

\subsection{Behavioral observations}

Detailed observations on oil-collecting behavior of males were carried for two species (T. diversipes and T. aff. peckoltii) on flowers of Heteropterys tomentosa A. Juss., over several days during June 2009 at RECOR. We documented details of their behavior by video recording using a Nikon Coolpix P80 camera, as well as focal observations. Films were later analyzed frame by frame using a VLC media player and were used to produce drawings illustrating the movements performed by males. Males observed collecting oils on flowers were easily distinguished from females in the field based on their distinctive hind leg morphology, hair pattern, and size.

\section{RESULTS}

\subsection{Morphology of oil-collecting structures}

Most structures of the oil-collecting apparatuses of male Tetrapedia are identical in shape and size to those of their respective females (Neff and Simpson 1981; Alves-dos-Santos et al. 2006). Thus, we concentrate our morphological analyses on those characteristics that are unique to males of Tetrapedia and indicate which structures are identical in both sexes. Differences in the size or shape of oil-collecting structures between males and females are indicated for both species.

Fore legs In all male Tetrapedia we have examined, the basitarsi have a curved carina on their "outer" margin, its basal portion being curved posteriorly. This carina bears the squeegee-like elaiospathe formed by an array of flattened setae (Figure 1a). These structures have the same size and shape as those of their respective females (Figure 1b). Males that have not been precleaned for SEM pictures commonly show residual oil on the setae of this comb (Figure 1a).

Mid legs The setal arrays of the midlegs of males are very similar to those of females. In both sexes, the tarsi have an array of moderately long, finely branched setae on the dorsal surface 

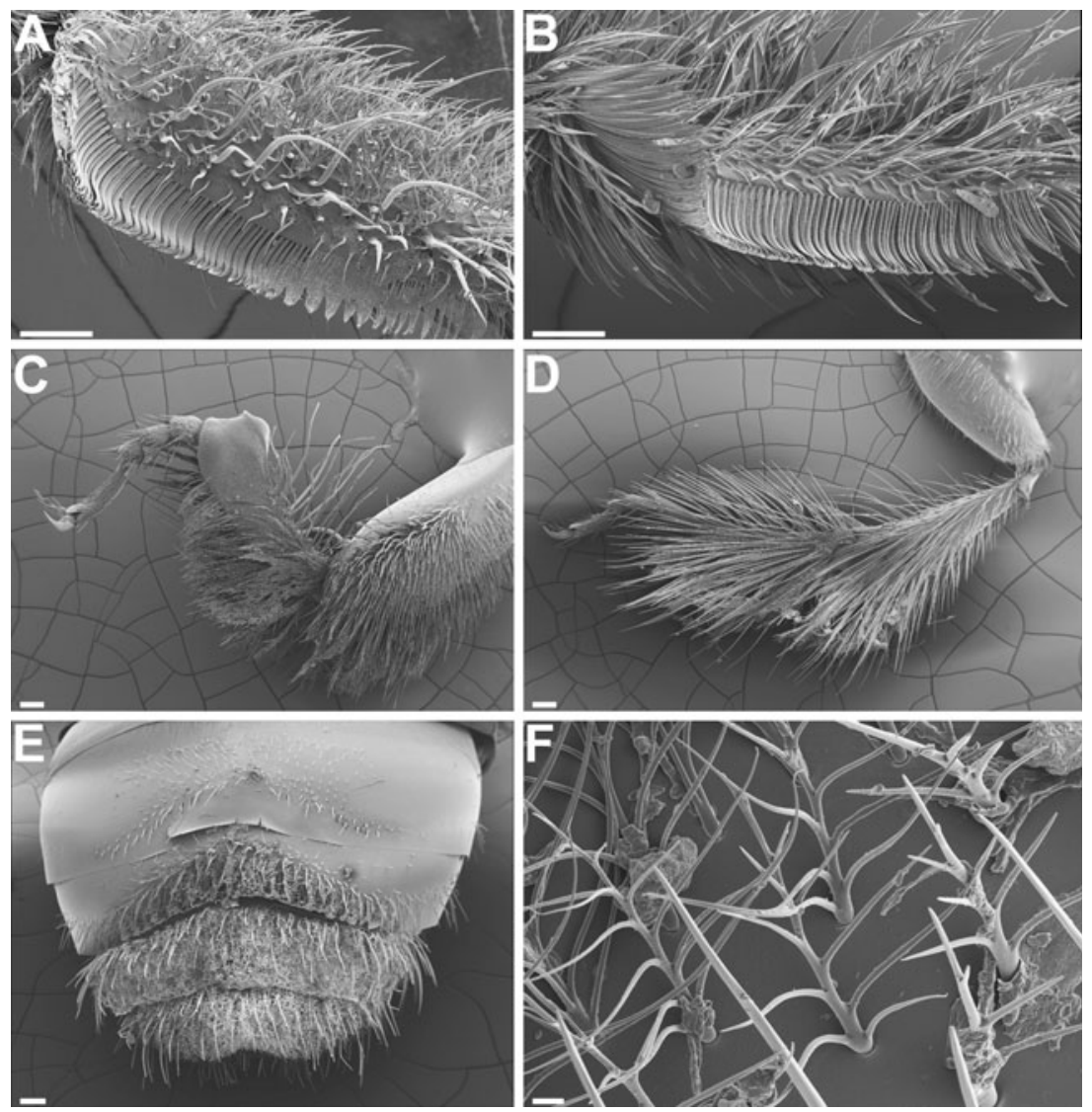

Figure 1. Oil-collecting and storage structures in males and females of $T$. diversipes $(\mathbf{a}, \mathbf{b}, \mathbf{e}, \mathbf{f})$ and $T$. aff. peckoltii (c, d). a Posterior view of male's oil-collecting apparatus on the fore leg with oil-soaked combs in the lower right corner, scale bar $=100 \mu \mathrm{m},(\times 500)$; b posterior view of the female oil-collecting apparatus on the fore leg, scale bar $=100 \mu \mathrm{m},(\times 500)$; c lateral view of male hind leg scopa, scale bar $=200 \mu \mathrm{m},(\times 80)$; d lateral view of female hind leg scopa, scale bar $=200 \mu \mathrm{m},(\times 70)$; e dorsal view of the male metasoma showing the tergal brush, scale bar $=200 \mu \mathrm{m},(\times 80)$; $\mathbf{f}$ detail of branched hairs from the male tergal brush, scale bar $=10 \mu \mathrm{m}$, $(\times 2,000)$; magnification levels in parentheses.

and an array of long, simple setae on the ventral surface. These arrays are similar to the mats of branched setae found on foretarsi of some Centridini and Tapinotaspidini associated with flowers with trichome elaiophores but here are believed to function only in the transfer of oils to the hind legs.

Hind legs The hind tibia and basitarsi of male Tetrapedia are highly modified relative to those of female Tetrapedia (Figure 1c, d). The hind tibiae and basitarsi of the female are relatively simple with a scopae of mixed arrays of long simple setae and shorter finely branched hairs (Figure 1d). In contrast, the hind tibia of the male is greatly swollen distally and nearly hairless, or sparsely hairy, except for a distal tuft of mixed simple and finely branched hairs (Figure 1c). The hind basitarsi of male Tetrapedia are enlarged and variously modified, usually with a flange or concavity on the anterior surface. Males have a row of erect branched setae on the posterior margin of the hind basitarsi that grades into a basal patch of branched setae 
on the outer basitibial surface (Figure 1c). Oily substances are commonly observed on the branched setae of both males and females.

Male tergal brush The setation of the distal terga of female Tetrapedia is typical for the Apidae with a well-formed, but unremarkable, prepygidial, and pygidial fimbria which consist of thick, bristle-like hairs located on the apical margin of the fifth tergum (Figure $2 a, d$ ). Fimbriae are used by females for "packing" nest materials (i.e., sand) while shaping and constructing nest cells (Alves-dos-Santos et al. 2002). In contrast, males of all species of Tetrapedia observed in this study have dense, mat-like arrays of short, finely branched setae mixed with fewer erect, simple setae on the apex of tergum 4 and covering most of the discs of terga 5 and 6 (Figs. 1e, f, 2b, c, e, f). This tergal brush is unique to Tetrapedia, and apparently functions as a storage structure for floral oils [see the description of oil transfer for further details].

\subsection{Male oil-collecting behavior}

Oil-collecting behavior by male Tetrapedia is essentially identical to that of female Tetrapedia: they land on the tip of one floral petal, crawl underneath, bite the floral pedicel with their mandibles (Figure 3a, b), and use their mid legs to hold onto flowers. Hanging upside down, they then scrape the surface of the elaiophores with their fore legs bent at about $90^{\circ}$ angle with the claws pointing away from their body (Figure 3a). They rotate underneath the flower to reach all pairs of glands. When the oil of all the elaiophores has been harvested, the male bee either "walks" to a different flower or flies up after throwing itself off the flower. Oil transfer by males typically happens in two steps: first, using their mid legs, males transfer the collected oil from their forelegs to their hind legs either while perching on a flower or during hovering flights. The second step seems to involve a transfer of oil from the hind legs to the tergal brush located on the tip of their
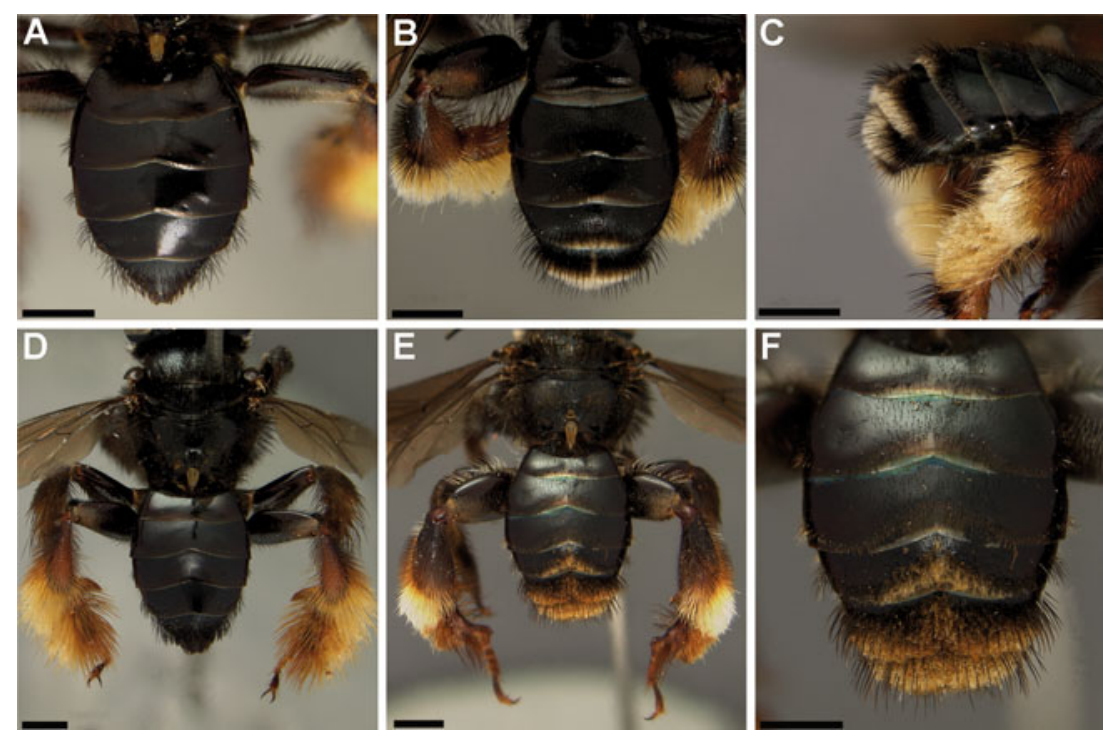

Figure 2. Comparison of metasomal morphology of male and female Tetrapedia in specimens of $T$. diversipes $(\mathbf{a}, \mathbf{b}, \mathbf{c})$ and $T$. aff. peckoltii $(\mathbf{d}, \mathbf{e}, \mathbf{f}) ;$ scale bars indicate $1 \mathrm{~mm}$. a Dorsal view of female metasoma, $(\times 90)$; b dorsal view of male metasoma, $(\times 90)$; $\mathbf{c}$ lateral view of distal terga showing the tergal brush, male's oil storage structure, $(\times 90)$; $\mathbf{d}$ dorsal view of female metasoma and hind legs, $(\times 45)$; e dorsal view of male metasoma and hind legs, $(\times 45)$; $\mathbf{f}$ close-up of male terga, with tergal brush on segments 4,5 , and $6,(\times 90)$; magnification levels in parenthesis. 
metasomas. In this step, males land on a flower and repeatedly rub their hind legs over their bent metasomas (Figures 3d, 4). After transferring the collected substances, males eventually return to a flower and sit on the flag petal, with their heads facing away from the center of the flower (Figure 3e, f). We observed males remaining in this position (Figure $3 \mathrm{f}$ ) for up to $3 \mathrm{~min}$. In a few cases, we noted in pictures taken to document this behavior that waiting males had their genitalia partially everted (Figure 3e), but it could not be determined if this behavior occurred consistently. While foraging for oil, females behave in a similar fashion as males, except that after visiting a few flowers, they depart from the area. Females lack the metasomal tergal brush and accordingly were not observed performing the second oil transfer. The arrival of a male usually results in the female leaving the inflorescence.

At the Tibagi site, males of Tetrapedia curvitarsis were observed collecting oils from Byrsonima brachybotrya Niedenzu (Malpighiaceae) in the morning of November 30, 2003 (Figure 3b; Table I). The first individual was seen at the flowers at 0910 hours and another at 0953 hours. They were photographed while collecting oil and then were collected immediately. When examined under a stereoscopic microscope the next day, both males had large quantities of oil in their hind tibial scopae.

Floral oil collection by males of $T$. aff. peckoltii was observed on inflorescences of Byrsonima coccolobifolia Kunth (Malpighiaceae) at the Serra do Salitre, Minas Gerais (Figure 3d; Table I). Several males were seen on the flowers. They frequently walked between nearby flowers and made short flights between the inflorescences.

At the Brasilia site, males and females of $T$. diversipes, T. aff. peckoltii, and Tetrapedia sp. were observed foraging for oils on flowers of five Malpighiaceae species (Banisteriopsis campestris (A. Juss.) Little, Byrsonima basiloba A. Juss., Heteropterys pteropetala A. Juss., $H$. tomentosa A. Juss., and Peixotoa goiana C. Anderson) during the wet and dry seasons (Table I). At this site, several males were observed foraging on flowers, and a total of 11 males were sampled after collecting oils from the respective Malpighiaceae species. Females of these species tended to be more frequent visitors on the flowers than their male counterparts (Table I). Intensive behavioral observations of males were made at flowers of $H$. tomentosa during June 2009 (Figure 3a, c, e, f). Males of $T$. diversipes, T. aff. peckoltii, and Tetrapedia sp. visited flowers of this species mainly during the morning (1000 to 1200 hours).

\section{DISCUSSION}

The presence of branched hairs on the distal metasomal terga of male Tetrapedia has previously been noted (Moure 1995; Alves-dosSantos et al. 2009), but their function was not understood. One suggestion was that this tergal brush might be involved in the stimulation of glandular secretions hypothesized to be produced in the hind legs (Alves-dos-Santos et al. 2009). Several authors have suggested that males of known oil-collecting taxa (including Tetrapedia) may be collecting floral oils based on visitation records and the presence of oils on the hind legs (Vogel and Machado 1991; Singer and Cocucci 1999). Vogel (1974) noted the presence of oils on the hind legs of males of Chalepogenus rufipes Roig-Alsina (as Tapinotaspis "rufipes") but suggested they were acquired from oil laden females during copulatory attempts. We here provide direct evidence that male Tetrapedia use the structures of their fore legs to collect floral oils in the same manner as do female Tetrapedia. No morphological differences were found between the oilcollecting structures in the fore legs of males and females of the Tetrapedia species observed in this study and both sexes lack oil-collecting structures on their mid legs. However, the oil storage structures in the examined males differ from those found in females in two important ways: (a) the male hindtibial scopae, although formed by the same kind of branched hairs found in female scopae, is reduced, and lacks the erect simple hairs; and (b) the dorsal surface 

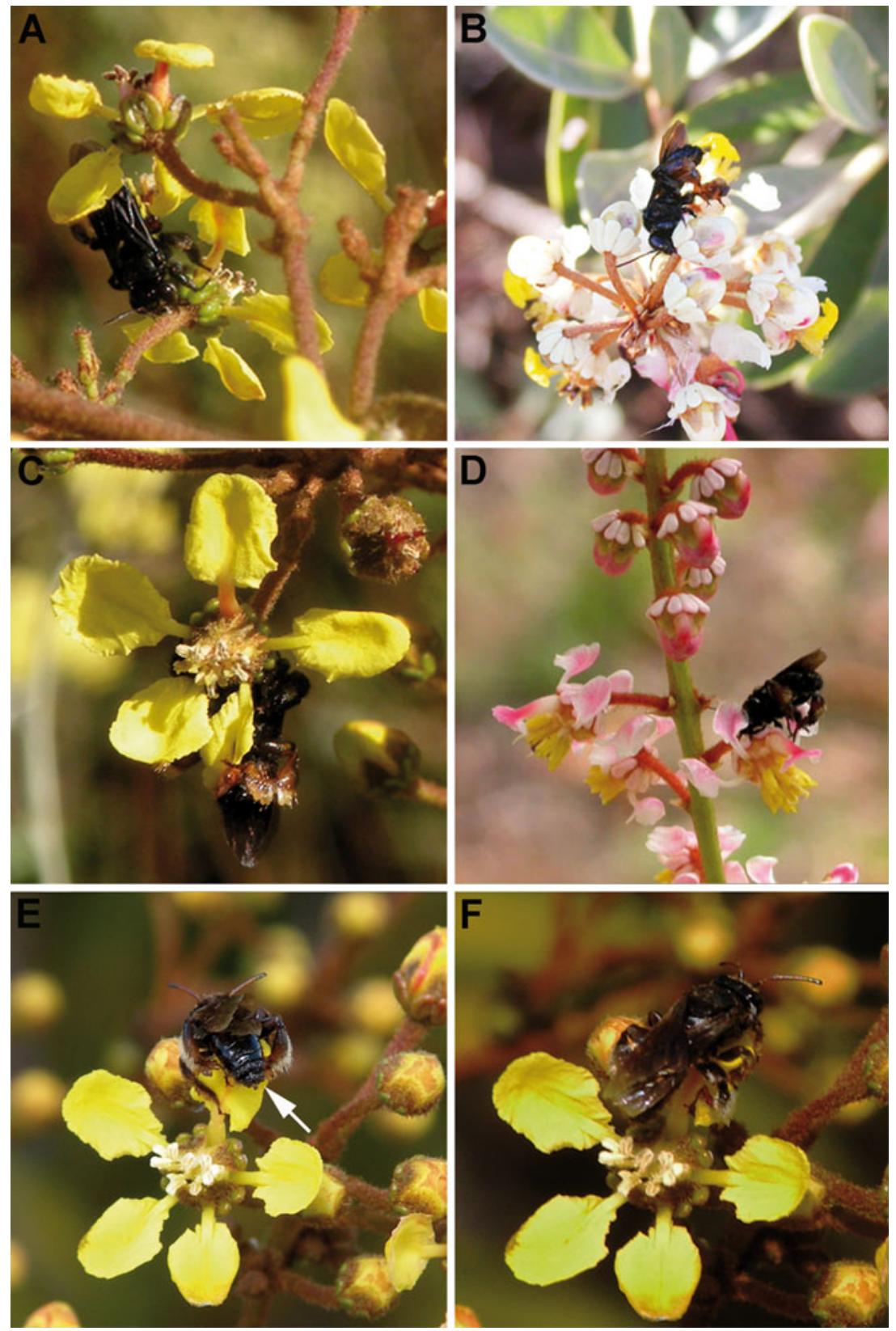

Figure 3. Behavioral aspects of oil collection by males of Tetrapedia diversipes (a), T. curvitarsis (b), and T. aff. peckoltii (c, d, e, f) on the oil flowers of Heteropterys tomentosa. (a, c, e, f), Byrsonima brachybotria (b), and Byr. coccolobifolia (d). a, b Males approach flowers from underneath, hold onto floral pedicels with mandibles, and scrape oils from elaiophores using their fore legs; c Males rotate underneath the flowers to reach all elaiophores, note shiny hairs on hind leg scopae loaded with oils; $\mathbf{d}$, e Oils are transferred from fore to hind legs and subsequently to the tergal brush. Arrow indicates tergal brush with oil-loaded hairs and the partly exerted male genitalia; f male with oil-loaded tergal brush positioned on the top of a flower. 


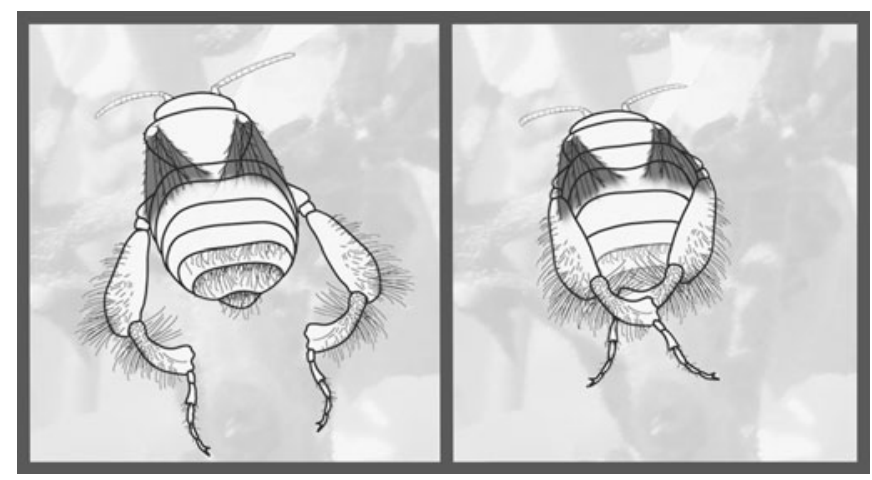

Figure 4. Line drawing based on video frames indicating sequence of leg movements performed after oil collection by perched males. The hind legs are rubbed against each other with subsequent scraping over the dorsal part of the bent metasoma to transfer the collected floral oils from the hind legs to the tergal brush. Wings reduced for better visualization of the tergal brush (drawing by G. Gage/B. Klein).

of the last three male terga have a tergal brush formed by branched and simple hairs. Although females of some Tetrapedia species display a fimbria composed by sets of bristles on the apical part of their fifth tergum, these bristles are mainly composed by single, stiff hairs, alternating with a few branched hairs (Alves-dos-Santos et al. 2002). These arrays of hairs are quite distinct from the branched hairs associated with the storage of oils in the female scopae and from those found on male distal terga. Hence, the tergal brush is clearly an oil storage structure found only in males of this genus.

Two other cases of morphological adaptations for the collection and storage of resources (besides nectar) have been reported in male bees and both are associated with mating tactics. Males of Anthophora abrupta Say (Apidae: Apinae: Anthophorini), a North American species, store volatiles previously collected from leaves in a "mustache" formed of fine hairs located on their labrum (Norden and Batra 1985). These vola-

Table I. Summary of floral oil-foraging records by males and females of Tetrapedia observed in this study.

\begin{tabular}{lllrrr}
\hline Site & Species & Oil hosts & $N$ (male) & $N$ (female) & Season \\
\hline Tibagi, Paraná & T. curvitarsis & Byr. brachybotrya & 2 & 2 & Wet \\
S. Salitre, Minas Gerais & T. aff. peckoltii & Byr. coccolobifolia & 1 & 0 & Wet \\
Brasília, Distrito Federal & T. diversipes & Ban. campestris & 1 & 3 & Wet \\
& & Het. pteropetala & 1 & 0 & Wet \\
& & Het. tomentosa & 4 & 14 & Dry \\
& T. aff. peckoltii & Ban. campestris & 2 & 0 & Wet \\
& & Byr. basiloba & 1 & 3 & Wet \\
& & Het. tomentosa & 1 & 1 & Dry \\
& Tetrapedia sp. $^{\text {a }}$ & Het. tomentosa & 1 & 2 & Dry
\end{tabular}

$N$ indicates the number of male and female individuals sampled at each shared oil host. Malpighiaceae genera: Ban.= Banisteriopsis, Byr. $=$ Byrsonima, Het. $=$ Heteropterys, and $P .=$ Peixotoa

${ }^{a}$ Undescribed species, with a mostly reddish brown color, apparently restricted to the Cerrado of central Brazil (G. A. R. Melo, unpublished data) 
tiles, in combination with mandibular secretions, are used to mark territories surrounding the foraging range of females (Norden and Batra 1985). Male orchid bees (Apidae: Apinae: Euglossini) collect volatiles, from several floral and non-floral sources, with specialized brushes on their fore legs, and store them inside special pockets located on their expanded hind legs (Dressler 1982; Roubik and Hanson 2004; Cappellari and Harter-Marques 2010). The mixed, stored volatiles are sprayed in the air to attract females (Eltz et al. 2003; Bembé 2004; Eltz et al. 2005). The evolution of the internal storage structure of male euglossine has been associated with the need to preserve highly volatile substances (i.e., floral scents) that could be lost following harvesting but needed to be accumulated over time for successful courtship (Eltz et al. 2005). Because the lipids collected by male Tetrapedia are fixed fatty oils, they are unlikely to be rapidly lost via evaporation so external storage probably is not a problem. In addition, storage of floral oils in an exposed structure, such as the tergal brush, could facilitate the contact with the female bees' sensory systems through visual, mechanical, or olfactory signals.

The collection of floral resources for mating purposes has also been observed in male bees that lack morphological adaptations to collect and transport resources. For instance, stingless bees (Apidae: Meliponini) from Thailand may use this strategy to have access to mates (Boongird and Michener 2010). In the stingless bee society, workers collect provisions for the brood, defend the colony, and construct nest cells while the queen lays eggs inside the nest upon the first nuptial flight during which she tends to mate with one male from a swarm (Michener 1974). Usually, males leave the nest upon emergence and do not participate in parental care. However, in some species of Meliponini mating can occur inside the nest requiring males to enter the colony and copulate with the queen (Boongird and Michener 2010). In these species, males that have hind legs loaded with pollen or resins can easily enter a nest even though they do not make a contribution to the food supplies of the colony while individuals not carrying resources are repelled by workers (Boongird and Michener 2010). Even though these males lack a corbicula, their hind legs greatly resemble those of workers and are covered with sparse hairs that can hold the collected floral resources. Thus, it is likely that males of these species use resins and pollen, both resources used for nest construction and larval feeding in stingless bees' colonies, to deceive workers and have access to mates (Boongird and Michener 2010).

Active oil foraging by males of Tetrapedia is remarkable among bees since studies on the nesting behavior of some species within this genus found no involvement by them in nest construction or brood cell provisioning (Alvesdos-Santos et al. 2002; Camillo 2005). Besides Tetrapedia, males from another oil-collecting bee group, Tapinotaspidini (with exception of Tapinotaspoides), display oil-collecting-like setal combs or pads on their fore legs, as well as tufts of branched hairs on their mid and hind legs. Although males of this tribe have plumose hairs on the pre-pygidial fimbria, they lack the distinctive tergal brush found in male Tetrapedia (Neff and Simpson 1981; Roig-Alsina 1997). Our personal field observations and those reported in the literature support the idea that some tapinotaspidine males collect floral oils as well although the use of floral oils by males of this group has yet to be reported (Friese 1925; Singer and Cocucci 1999; Rasmussen and Olesen 2000; Aguiar and Melo 2009). Collection, storage, or use of floral oils by males has never been reported for any species in the Centridini, the most diverse of all oil-collecting tribes in the Neotropical region. In fact, Centridini males have reduced oil-collecting apparatuses and strongly reduced scopae when compared to females (Neff and Simpson 1981).

The differences in male foraging behavior and structures among Neotropical oil-collecting bees is perhaps not surprising given that these tribes are distantly related, and oil-collecting behavior likely evolved independently in each one of them (Cardinal et al. 2010). According to the most recent phylogeny, the closest relatives of the Tetrapediini are the carpenter bees 
(Apidae: Xylocopinae), a clade lacking oilcollecting taxa. The mating strategies of male xylocopines include territorial displays at landmarks, the use of pheromones for scent marking, and mating at flowers (Marshall and Alcock 1981). However, no xylocopines are known to use collected floral resources to attract mates (Anzenberger 1977; Minckley and Buchmann 1990; Alcock 1991; Leys and Hogendoorn 2008).

\subsection{Potential role of floral oils in mating of Tetrapedia}

Nothing is known about copulatory behavior in Tetrapedia. Therefore, our discussion is based on our observations, the literature on nesting biology of the genus, as well as data on mating in bees, and aims to provide some hypotheses for the use of floral oils by males of this genus. Females of most solitary bees mate shortly after emergence and the availability of receptive females often is a limiting factor to male reproductive success (Eickwort and Ginsberg 1980; Roubik 1992; Ayasse et al. 2001; Paxton 2005). High malemale competition for access to females is likely to select for mating strategies that maximize male's encounter rate with females (Thornhill and Alcock 1983; Ayasse et al. 2001). Among bees, strategies to enhance the encounter rate include: (a) searching for mates at emergence sites; (b) attracting mates to landmarks or display sites, or (c) finding mates at flowers (Alcock et al. 1977, 1978; Eickwort and Ginsberg 1980; Thornhill and Alcock 1983; Paxton 2005). Occurrence of these strategies tends to be correlated with the distribution of nests and the likelihood of encountering females at various sites.

Mating at emergence sites commonly occurs in species that nest gregariously or otherwise have high nest densities. Male reproductive success is often enhanced by patrolling emergence sites where males are likely to encounter virgin females (Alcock et al. 1976; Eickwort and Ginsberg 1980). This strategy has not been observed in Tetrapedia since females do not nest gregariously under natural conditions and males do not patrol nest entrances or emergence sites (Alves-dos-Santos et al. 2002; Camillo 2005).
The other two strategies, mating at display sites and at floral resources used by females, are associated with low nest density (Alcock et al. 1978; Paxton 2005). Mating at landmarks or display sites in which males tend to position themselves on plants that occur in foraging routes used by females and use pheromones for attraction, as has been observed in Xylocopa, could be a possible strategy that has not yet been observed in Tetrapedia. This strategy tends to be associated with long-distance fliers, typically larger bees and may not be appropriate for relatively small-bodied bees like Tetrapedia (Thornhill and Alcock 1983). Mating at flowers is the most common strategy among bees with dispersed nests, and is particularly common among oligolectic species with a limited range of floral hosts. Some Tetrapedia are polylectic and collect pollen from a wide range of pollen hosts (Alves-dos-Santos et al. 2002; Siqueira Neto et al. 2007). Such foraging patterns make locating potential mates at flowers more difficult, so searching for mates at the more limited set of oil-producing flowers utilized by Tetrapedia females may be more profitable. A similar strategy may occur in another oil-collecting bee, Macropis nuda (Provancher) where within a day, males initially patrol the nest site or emergence site, then move to nectar flowers and finally patrol, and attempt to copulate with females at their oil and pollen sources (Cane et al. 1983). Unlike Tetrapedia, Macropis is oligolectic, restricting its pollen collection to flowers of Lysimachia (Myrsinaceae), which is also its floral oil host. Although we do not have extensive information on nectar and pollen sources used by Tetrapedia at our field sites, our records at the Brasília site indicate high overlap between males and females on oil floral hosts. Since there are many potential nectar and pollen hosts in these complex communities, oil hosts blooming at times coinciding with emergence of males in these multivoltine species may serve as reliable sites to encounter potential mates. This hypothesis is further supported by our observations that show overlap in visitation by males and females to oil flower species, and other studies that report males of this genus patrolling oil flowers used by 
their female counterparts for foraging (Vogel 1974; Neff and Simpson 1981; Vogel and Machado 1991).

Even though mating was not observed at the flowers, Tetrapedia males' behavior of sitting on the flag petal of the flower with an oil-loaded tergal brush may represent a strategy to have access to, and perhaps surprise, mates at their floral hosts. Males bearing significant loads of floral oils may smell like the floral oils sought by females and could thus become less conspicuous to them. These chemically disguised males may be using an ambush strategy to enhance their access to virgin, or perhaps even previously mated females. Alternatively, males perched on flowers could be more easily evaluated by potential mates and the floral oils stored on their bodies could function as an attractant to receptive females, as has been observed in some species of Xylocopa (Marshall and Alcock 1981). Another possibility is that floral oils stored in the tergal brush may serve as a carrier for volatile compounds secreted by the males which in turn play some role in mating or mate attraction. Clearly, more observations and chemical analyses are necessary to clarify the use of floral oils by male Tetrapedia.

\section{ACKNOWLEDGMENTS}

SCC thanks Rosana Tidon for the research and logistic support, staff of the Reserva Ecológica do IBGE for the field work support, and Christian Rabeling for the help with SEM photographs. All authors thank Maria C. Mamede for the plant voucher identification, Gwen Gage and Barrett Klein for the illustrations of the bee behavior, and Beryl B. Simpson for the critical input on earlier versions of this manuscript. This research was partly funded by Dorothea Bennett Travel Grants, Section of Integrative Biology, UT Austin and a National Science Foundation-Doctoral Dissertation Improvement Grant (DEB-0909511) to SCC. AJCA thanks Fundação de Apoio à Pesquisa do Distrito Federal for financial support (proc.no. 193.000.563/2009); GARM thanks the Conselho Nacional de Desenvolvimento Científico e Tecnológico (CNPq) for a PQ-2 fellowship.

Récolte d'huile florale par les mâles de Tetrapedia (Hym. : Apidae: Tetrapediini)
Cerrado / accouplement / région néo-tropicale / abeilles récolteuses d'huile / abeilles solitaires

\section{Das Sammeln von floralen Ölen durch Tetrapedia- Männchen (Hymenoptera: Apidae: Tetrapediini)}

\section{Cerrado / Paarung / Neotropis / ölsammelnde Bienen / Ölblumen / solitäre Bienen}

\section{REFERENCES}

Aguiar, A.J.C., Melo, G.A.R. (2009) Notes on oil sources for the bee genus Caenonomada (Hymenoptera, Apidae, Tapinotaspidini). Rev. Bras. Entomol. 53, 154-156

Alcock, J. (1991) Mate-locating behavior of Xylocopacalifornica-arizonensis Cresson (Hymenoptera, Anthophoridae). J. Kans. Entomol. Soc. 64, 349-356

Alcock, J., Jones, C.E., Buchmann, S.L. (1976) Location before emergence of female bee, Centris pallida, by its male (Hymenoptera-Anthophoridae). J. Zool. 179, 189-199

Alcock, J., Jones, C.E., Buchmann, S.L. (1977) Male mating strategies in bee Centris pallida Fox (Anthophoridae-Hymenoptera). Am. Nat. 111, 145-155

Alcock, J., Barrows, E.M., Gordh, G., Hubbard, L.J., Kirkendall, L., Pyle, D.W., Ponder, T.L., Zalom, F.G. (1978) The ecology and evolution of male reproductive behaviour in the bees and wasps. Zool. J. Linn. Soc. 64, 293-326

Alves-dos-Santos, I., Melo, G.A.R., Rozen Jr., J.G. (2002) Biology and immature stages of the bee tribe Tetrapediini (Hymenoptera: Apidae). Am. Mus. Novit. 3377, 1-45

Alves-dos-Santos, I., Naxara, S.R.C., Patricio, E.F. (2006) Notes on the morphology of Tetrapedia diversipes Klug 1810 (Tetrapediini, Apidae), an oilcollecting bee. Braz. J. Morphol. Sci. 23, 425-430

Alves-dos-Santos, I., Machado, I.C., Gaglianone, M.C. (2007) História natural das abelhas coletoras de óleo. Oecologia Brasiliensis 11, 544-557

Alves-dos-Santos, I., Gaglianone, M.C., Naxara, S.R., Engel, M.S. (2009) Male sleeping aggregations of solitary oil-collecting bees in Brazil (Centridini, Tapinotaspidini, and Tetrapediini; Hymenoptera: Apidae). Genet. Mol. Res. 8, 515-524

Anzenberger, G. (1977) Ethological study of African carpenter bees of the genus Xylocopa (Hymenoptera, Anthophoridae). Z. Tierpsychol. 44, 337-374

Ayasse, M., Paxton, R.J., Tengo, J. (2001) Mating behavior and chemical communication in the order hymenoptera. Annu. Rev. Entomol. 46, 31-78

Bembé, B. (2004) Functional morphology in male euglossine bees and their ability to spray fragrances (Hymenoptera, Apidae, Euglossini). Apidologie 35, 283-291 
Boongird, S., Michener, C.D. (2010) Pollen and propolis collecting by male stingless bees (Hymenoptera: Apidae). J. Kans. Entomol. Soc. 83, 47-50

Camillo, E. (2005) Nesting biology of four Tetrapedia species in trap-nests (Hymenoptera: Apidae: Tetrapediini). Rev. Biol. Trop. 53, 175-186

Cane, J.H., Eickwort, G.C., Wesley, F.R., Spielholz, J. (1983) Foraging, grooming and mate-seeking behaviors of Macropis nuda (Hymenoptera, Melittidae) and use of Lysimachia ciliata (Primulaceae) oils in larval provisions and cell linings. Am. Midl. Nat. 110, 257-264

Cappellari, S. C., Harter-Marques, B. (2010) First report of scent collection by male orchid bees (Hymenoptera: Apidae: Euglossini) from terrestrial mushrooms. J. Kans. Entomol. Soc. 83, 264-266

Cardinal, S., Straka, J., Danforth, B.N. (2010) Comprehensive phylogeny of apid bees reveals the evolutionary origins and antiquity of cleptoparasitism. Proc. Nat. Acad. Sci. USA 107, 16207-16211

Cocucci, A.A. (1991) Pollination biology of Nierembergia (Solanaceae). Plant Syst Evol 174, 17-35

Dressler, R.L. (1982) Biology of the orchid bees (Euglossini). Annu. Rev. Ecol. Syst. 13, 373-394

Eickwort, G.C., Ginsberg, H.S. (1980) Foraging and matingbehavior in Apoidea. Annu. Rev. Entomol. 25, 421-446

Eltz, T., Roubik, D.W., Whitten, M.W. (2003) Fragrances, male display and mating behaviour of Euglossa hemichlora: a flight cage experiment. Physiol. Entomol. 28, 251-260

Eltz, T., Sager, A., Lunau, K. (2005) Juggling with volatiles: exposure of perfumes by displaying male orchid bees. J. Comp. Physiol. A Sens. Neural. Behav. Physiol. 191, 575-581

Friese, H. (1925) Neue neotropische Bienenarten, zugleich II, Nachtrag zur Bienenfauna von Costa Rica (Hymenoptera). Stutt. Entomol. Zeit. 86, 1-41

Leys, R., Hogendoorn, K. (2008) Correlated evolution of mating behaviour and morphology in large carpenter bees (Xylocopa). Apidologie 39, 119-132

Marshall, L.D., Alcock, J. (1981) The evolution of the mating system of the carpenter bee Xylocopa varipuncta (Hymenoptera: Anthophoridae). J. Zool. 193, 315-324

Michener, C.D. (1974) The social behavior of the bees. The Belknap Press of Harvard University Press, Cambridge

Michener, C.D. (2007) The bees of the world, 2nd edn. The John Hopkins University Press, Baltimore

Michener, C.D., Lange, R.B. (1958) Univ. Kans. Sci. Bull 39, 69-96

Minckley, R.L., Buchmann, S.L. (1990) Territory site selection of male Xylocopa (Neoxylocopa) varipuncta Patton (Hymenoptera, Anthophoridae). J. Kans. Entomol. Soc. 63, 329-339

Moure, J.S. (1995) Redescrição de alguns exemplares tipos de espécies neotropicais de Tetrapedia Klug, descritos por Friese em 1899 (Apoidea, Anthophor- idae). I. Espécies pertencentes a Tetrapedia (s. str.). Rev. Bras. Zool. 12, 915-926

Moure, J.S. (2007) Tetrapediini Michener \& Moure, 1957. In: Moure, J.S., Urban, D., Melo, G.A.R. (Orgs). Catalogue of Bees (Hymenoptera, Apoidea) in the Neotropical Region, Sociedade Brasileira de Entomologia, Curitiba

Neff, J.L., Simpson, B.B. (1981) Oil-collecting structures in the Anthophoridae (Hymenoptera): morphology, function, and use in systematics. J. Kans. Entomol. Soc. 54, 95-123

Norden, B.B., Batra, S.W.T. (1985) Male bees sport black mustaches for picking up parsnip perfume (Hymenoptera-Anthophoridae). Proc. Entomol. Soc. Wash. 87, 317-322

Paxton, R.J. (2005) Male mating behaviour and mating systems of bees: an overview. Apidologie 36, 145-156

Rasmussen, T.J., Olesen, J. (2000) Oil flowers and oil collecting bees. Det Norske Videnskaps 39, 23-31

Renner, S.S., Schaefer, H. (2010) The evolution and loss of oil-offering flowers: new insights from dated phylogenies for angiosperms and bees. Phil. Trans. R. Soc. B 365, 423-435

Roig-Alsina, A. (1997) A generic study of the bees of the tribe Tapinotaspidini, with notes on the evolution of their oil-collecting structures (Hymenoptera: Apidae). Mitt. Münch. Entomol. Gesell. 87, 3-21

Roubik, D.W. (1992) Ecology and natural history of tropical bees. The John Hopkins University Press, Baltimore

Roubik, D.W., Hanson, P.E. (2004) Orchid bees of tropical America: biology and field guide. InBIo Press, Heredia

Silveira F.A., Melo G.A.R., Almeida E.A.B. (2002) Abelhas Brasileiras: Sistemática e Identificação, F. A. Silveira, Belo Horizonte

Singer, R.B., Cocucci, A. (1999) Pollination mechanisms in four sympatric southern Brazilian Epidendroideae orchids. Lindleyana 14, 47-56

Siqueira Neto H., Oliveira R., Schlindwein C. (2007) Polilectia em Tetrapedia: fêmeas buscam pólen de numerosas espécies na floresta Atlântica de Pernambuco. Conf. Proc. VIII Congresso de Ecologia do Brasil, [online] http://www.seb-ecologia.org.br/viiiceb/ pdf/1754.pdf (Acessed on 30 November 2010).

Thornhill, R., Alcock, J. (1983) The evolution of insect mating systems. Harvard-University Press, Cambridge

Vogel, S. (1974) Ölblumen und ölsammelnde Bienen. Trop. Subtrop. Pflanzenwelt 7, 1-267

Vogel, S., Machado, I.C. (1991) Pollination of 4 sympatric species of Angelonia (Scrophulariaceae) by oil-collecting bees in NE Brazil, Plant Syst. Evol. 178, 153-178

Wirtz, P., Szabados, M., Pethig, H., Plant, J. (1988) An extreme case of interspecific territoriality -male Anthidium manicatum (Hymenoptera, Megachilidae) wound and kill intruders. Ethology 78, 159-167

Wittmann, D., Blochtein, B. (1995) Why males of leafcutter bees hold the females' antennae with their front legs during mating. Apidologie 26, 181-195 